\title{
Corporate Governance Effect on Ownership and Control in Firms: An Empirical Evidence from Pakistan
}

\author{
Rohail Hassan ${ }^{1} \&$ Maran Marimuthu ${ }^{1}$ \\ ${ }^{1}$ Department of Management \& Humanities, Universiti Teknologi PETRONAS (UTP), Tronoh, Malaysia \\ Correspondence: Rohail Hassan, Department of Management \& Humanities, Universiti Teknologi PETRONAS \\ (UTP), Tronoh, Perak, 31750, Malaysia. Tel: 60-11-1641-6168. E-mail: rohail.hassan39@gmail.com
}

Received: March 3, 2015

Accepted: May 19, $2015 \quad$ Online Published: July 22, 2015

doi:10.5539/ijbm.v10n8p212

URL: http://dx.doi.org/10.5539/ijbm.v10n8p212

\begin{abstract}
The paper focuses on Corporate Governance (CG) impact on the ownership and control of firms in Pakistan. It also explores legal protection of managers and investors rights in companies. Corporate Governance is considered as a core element when we talk about economic performance and to enhance investor's trust. Further on, it defines the structure, methods, control and processes of a company to achieve corporate objectives and targets under transparent strategies. CG enhances maximize shareholder value through transparency and accountability which increased firm's performance. In this study, a model presented that shows the effect of effective corporate governance mechanism in reducing the ownership and control problem among the organizational members of the company. The technique which used to collect data from the stakeholders of various companies was questionnaire method. The result of the study shows that effective corporate governance mechanism is the best practice to reduce the ownership and control problems in the organizations. The clear company policies and objectives are also the major contributor in reducing the principle agent problem in the firms.
\end{abstract}

Keywords: corporate governance (CG), ownership, control, shareholders, managers, directors role, agency problem

\section{Introduction}

Corporate governance is a subject and tool that ensure processes and structure which maximize the shareholder value through good management practices. The effective corporate governance mechanism is essential area of research now a days. Good corporate governance ensures the protection of individual and all interested parties through accountability and transparency which reduces the ownership and control problem in the organization. The primary purpose to achieve the organizational goals and maintain relationship among principal including board of directors and stakeholder of a company. Effective corporate governance may have significant impact on the strategic decision of a company, e.g. financial strategies, human resource strategies that are taken at top management level. Therefore, corporate governance variables like board structure, company policies and objectives and board structure may have directly impact of firm performance. In this dynamic financial markets, companies required to gain competitive edge through effective corporate governance.

In the last two decades, corporate governance gained too much attention of researchers. Companies are facing agency problems. The core issue in companies is ownership and control of firms. The ownership and control problem may lead to many issues related to control of company and all interested parties (Berle \& Means, 1932). In view of agency problem many researches has been done in corporate governance area. Core (1999) found that agency problem greater in those companies where have weaker corporate governance to direct and mange company affairs. Managers use companies resources own benefits which cause of lower firm performance. Therefore, firms need to improve corporate governance (CG) mechanism in order to sustain long term in this competitive environment. To ensure an effective corporate governance mechanism can be maintained in the firms by ensuring balance between the ownership and interested parties of the firm. This approach might reduce agency problem in the firms.

In recent years, corporate governance has received too much importance in corporate sector. The country like Pakistan comes under developing category, corporate governance considered as pillar for growth and development in the whole country. Government of Pakistan is ensuring to implement an effective corporate 
governance mechanism in the public and private sector companies.

\subsection{Aim of the Article and Research Questions}

This paper is focused on corporate governance from various perspectives and tries to check the effect of corporate governance mechanism in reducing the ownership and control problems among the member of the firms. This research study gives an overview that how corporate governance resolves agency problem. With different views, good corporate governance mechanism will help to determine ownership and control problem and tried to solve principal-agent problems.

\subsection{Methods Used in Research}

In this study the responses get from different people at different designation from five major companies of Pakistan. The methods adopted are personal interviews and by distributing questionnaires which suggest that there should be a proper implementation of corporate governance mechanism in the firms to eliminate the ownership and control problems. The implementation of corporate governance will define the clear policies to the shareholders and managers about the firm. The clear job and role of each individual in the firm makes it clear to differentiate the interests of shareholders with that of managers and CEOs and the principle agent problem will reduced. We, in our study take the corporate governance as the major variable and present a hypothesis that effective corporate governance mechanism leads to the reduction in ownership and control among managers and shareholders in the firm.

\subsection{Conclusions}

Results shows that there is a correlation among the effective corporate governance mechanism, clear company policies and objectives, clear role and authority and ownership control. The result indicates that there is a strong relationship ownership mechanism with clear company policies and objectives.

This paper is organized as follows. In section 2, literature review and importance of corporate governance are given. In section 2.3, corporate governance issues in Pakistan is discussed. The research methodology in this paper with theoretical framework are also presented in section 3. Finally, our findings of this paper is summarized in the two last section.

\section{Literature Review of Corporate Governance}

\subsection{Definition \& Importance of Corporate Governance}

In this dynamic era, corporate governance is considered as strong pillar because advance firms maintain separation of company managers and company owners. The same time agency problem is raised due to conflict of interest between the management firm's stakeholders. There are many definition of corporate governance with different angles. Here, some of important definition is discussed to understand main functions of corporate governance.

Definition: Berle and Means (1932) defined corporate governance as "Distribution of functioning head like ownership, capital structure, organization structure, takeovers, managerial incentives and labor market competition etc, could be all factors that affect the firm process (p. 4)".

Definition: Shleifer and Vishny (1997) defined "Suppliers of financial funds to firms assure themselves of getting better return on their investment known as corporate governance (p. 737)".

Definition: Oman (2001) defined "A set of rules, laws and policies which ensure the smooth relationship between company managers and stakeholders of firm known as corporate governance.

Definition: La Porta (2000) viewed, "corporate governance is a system in which shareholders protect themselves from inside managers".

\subsection{Corporate Governance \& Agency Theory}

In view of literature, governance is known as the mode in which the functions are conducted. Corporate governance is the tool which helpful to run functions of a firm (Note 1). The corporate governance comprises elements of accountability, transparency, creditability and trust, which is presented in the past studies of the topic.

McColgan (2001) argued critically on agency theory and corporate governance. He focused on area where the interest of agent diverge from those of the interests of principal. Jensen and Meckling (1976) considered that if there is any conflict among company managers and company owners raise the agency cost. Himmelberg et al. (1999) argued that principal agent problems is not same in al firms, these issues varies company to company and depend on different cultures. Effective corporate governance mechanism can eliminate agency problem. Agency 
problems in the organizations always cause of lower performance. Researcher argued that governance mechanism should be designed according to firm environment. One corporate governance mechanism can be important for some organizations and less important for other organizations (McColgan P., 2001).

In addition, researchers looked corporate governance issues and challenges in Africa. Many non-financial corporations had shut down in US and Asia region due to the non-effective corporate governance mechanism. Firms those are operating in Africa can learn from these experiences. Modern concepts of corporate governance is an important issue in research. Corporate governance emphasizes that organizations should maintain balance between company agents and shareholders. Okeahalam and Akinboade (2003) stated that Africa corporate companies should promote effective corporate governance through transparency and accountability that enhance the investor interest in companies.

Farinha (2003) argued that conflict between agent and principal in firms with regard to ownership mechanism. Agency problem occurred due to conflict in interest. Effective corporate governance can ensure by structure of board of directors, increasing number of shareholders, maximize the internal ownership and compensation packages. Novikova (2004) argued that internal corporate governance system on firms bring transparency in firm and better decision making which base on mutual understanding. Becher and Campbell (2004) found that Interests of directors relatively lies with the size of the company rather than performance. Kowalewski, Stetsyuk and Talavera (2007) found that empirical investigation of corporate governance is an important part to explain dividend policies.

\subsection{Corporate Governance in Pakistan}

Securities and Exchange Commission of Pakistan (SECP) established the Code of Corporate Governance code in March 2002. The primary purpose of this code is to establish a framework for good corporate governance practices in companies listed on Pakistan stock exchanges. Corporate governance reforms in Pakistan, the code of corporate governance is the major step. The code consist of many recommendations and guidelines in line with international good practice. (Note 2) According to SECP "CG is refer to describe a processes and procedures, which has been practiced corporate entities. This function ensure that the business activities and management of these corporate entities are practicing same standards which promote the interests of all corporate stakeholders". (p. 1)

The business and management of corporate entities in Pakistan were governed according to guidelines, which included the requirement for transparency and accountability in company practices. As the company grow in size the complexity in business environment increases. SECP suggested that such an affective mechanism of corporate governance should be implemented in the organizations by which companies must be directed and controlled. The system should focus on the responsibilities and authorities of the managers and directors and should engage them in setting strategies and establish and implement the clear policies. The accountability mechanism should always lie with the shareholders and managers for their activities and performance. The main objective of all stakeholders should be the enhancement of business performance of the companies and conformance with the laws, rules and practices of corporate governance (Note 3).

\section{Research Methodology}

\subsection{Theoretical Framework for Effective Corporate Governance Mechanism}

The definition of CG will be given by Sir Adrian Cadbury tiled (the Cadbury Report) (Note 4).

"Corporate governance is set of procedure and processes by which firms are directed and controlled. Company board of directors are responsible for the corporate governance practices. Shareholders (principal) role in corporate governance is to appoint directors, auditors to establish an appropriate governance structure. The primary responsibilities of BODs to establish company strategic aims, supervision of management teams and ensure transparency in system to satisfy shareholders". (p. 5) According to OECD perspective that corporate governance includes roles of stakeholders, duties and responsibilities of board members and right of shareholders known as CG (Note 5):

Keeping in view above literature and definitions we propose our model for implementation of effective CG mechanism and resolving the ownership and control problems in the firms. The below Figure 1 shows the relationship among independent and dependent variables. The independent (investigating) variables are effective CG mechanism, clear company policies \& objectives and clear role and authority. The dependent variable of this study ownership and control in firm. The following hypothesis developed after extensive literature. 
Corporate Governance Effect \& Ownership, Control in Firms

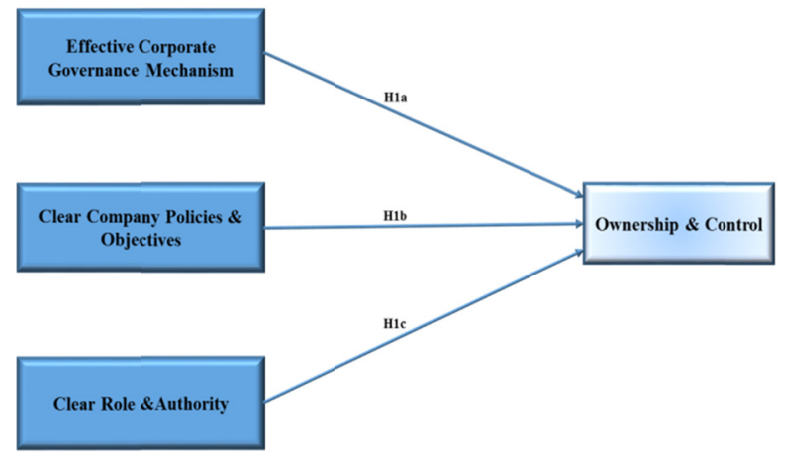

Figure 1. Model for effective corporate governance mechanism

Hypothesis 1a: Effective corporate governance mechanism reduces the ownership and control conflicts among the directors, shareholders and managers of the firm.

Hypothesis 1b: Effective corporate governance mechanism clearly defines the company policies and procedures to, directors, shareholders and managers of the firm

Hypothesis 1c: Effective corporate governance mechanism clearly differentiates the role and authority to directors, shareholders and managers of the firm.

This study hypothesized that clear company policies and objectives and clear role and authority of directors, shareholders and managers as major contributors for reducing ownership and control conflicts in the firms. This methodology section includes theoretical framework of this study, sampling, instrument and data analysis.

\subsection{Sample}

Furthermore, the effective corporate governance mechanism in the corporate so the participants of the study were director, shareholder, and manager from various management levels. The respondents were from the four main financial institutions of Pakistan. The total population study was 644 out of which 400 managers, shareholders and directors were taken as the sample. All the respondents are currently working in those companies. Data collected from 75 female and 325 male.

\subsection{Instruments}

The questionnaire consisted of following parameters: designation of the respondent in the firm, clear company policies and objectives, clear role and authority of respondent in the company and effective corporate governance mechanism towards the elimination of ownership and control. For this study, the questionnaire was adopted to measure the above parameters. We, include the question separately for each measure. The scale used for this study was Likert scale. The range of scale from "1" as strongly disagree to "5" as strongly agree and other responses are measured as " 1 " as very low to " 5 " as very high.

\subsection{Data Analysis}

In this paper, we used, SPSS 20.0 statistical packaged for data analysis. However, to check the predictability of the independent variable on dependent variables through different statistical tests like correlations ad simple regression analysis. Correlation test applied to see the correlation association among all variables (Table 1). Effective corporate governance mechanism, company policies and objectives, clear role and authority of employee were taken as independent variables and the dependent variables was ownership and control.

\section{Results and Discussions}

For this study, statistical test like correlation and simple linear regression were used. Table 1 shows the correlations among the effective corporate governance mechanism, clear company policies and objectives, clear role and authority and ownership control. The result shows that there is a positive significant relationship ownership and control mechanism with clear company policies and objectives at 0.05 significance level. However, clear company policies and objectives is positively associated with ownership and control of firm which means better clarity of company polices and objective lower the agency problem and there is no correlation between clear role and authority and Ownership \& control of firm. It can be concluded that clear company polices and objective to everyone lesser ownership and control problems. Hence, result of 2-Tailed is a 
positive statistically significant correlation clear company policies and objectives and ownership \&control of firm.

Table 1. Correlations among the variables

\begin{tabular}{lcccc}
\hline Variables & $\begin{array}{c}\text { 1. Effective CG } \\
\text { mechanism }\end{array}$ & $\begin{array}{c}\text { 2. Clear Company Policies \& } \\
\text { Objectives }\end{array}$ & $\begin{array}{c}\text { 3. Clear Role and } \\
\text { Authority }\end{array}$ & $\begin{array}{c}\text { 4. Ownership and } \\
\text { Control }\end{array}$ \\
\hline 1. Effective CG mechanism & 1 & .007 & .001 & .013 \\
2. Clear Company Policies \& & & 1 & -.040 & $.127^{*}$ \\
Objectives & & & 1 & .015 \\
3. Clear Role and Authority & & & 1 \\
4. Ownership and Control & & &
\end{tabular}

Table 2 presents results of the simple linear regression among independent and dependent variables. The first item effective corporate governance mechanism is regressed with ownership and control. There is an insignificant relationship between these two variables at $0.05 \mathrm{p}$-vale. The results of regression test is showing 3\% variance which is not supported to hypothesis 1 (a). As per hypothesis 1(b) when a firm has clear policies and objectives as independent variable and ownership and control as dependent variable, variance $6.5 \%$ and correlation results is 0.127 which is significant relationship. So, these results supported to our second hypothesis. Third variable clear role and authority regressed with ownership and control. The result of regression test is showing $2 \%$ variance. Correlation results shows that there is insignificant relationship among variables. So these result is not supported to hypothesis 1 (c). Overall, the results are supported the hypothesis H1 (b) stated above which shows clear company policies and objectives as highly significant variable of eliminating the conflicts of ownership and control between managers and shareholders in the companies. Now as predicted in my model that company clear policies and objectives and clear role and authority of individual associated with the company are used as moderating variable between independent and dependent variables in my framework of corporate governance effect on ownership and control of managers and shareholders in firms of corporate sector. After observing the effect of corporate governance on agency problem, we can check mediation effect of company policies and objectives and clear role and authority in between effective corporate governance mechanism and ownership and control. Because we considered to test the dependence of eliminating conflicts of ownership and control by implementing the effective corporate governance mechanism my result supported these hypotheses. To see the meditation effect, we will consider in second phase of this study.

Table 2. Regression test of ownership and control

\begin{tabular}{lccccc}
\hline Variables & Sum of Squares & df & Mean Square & F & Sig. \\
\hline $\begin{array}{l}\text { 1. Effective corporate governance } \\
\text { mechanism }\end{array}$ & 10.94 & 2 & 5.47 & 3.30 & $.038^{\mathrm{a}}$ \\
$\begin{array}{l}\text { 2. Clear company policies and } \\
\text { objectives }\end{array}$ & 10.84 & 1 & 10.84 & 6.56 & $.011^{\mathrm{b}}$ \\
\begin{tabular}{l} 
3. Clear role and authority \\
\hline
\end{tabular} & 11.21 & 3 & 3.73 & 2.25 & $.082^{\mathrm{c}}$ \\
\hline
\end{tabular}

a. Predictors: (Constant), Clear Company Policies \& Objectives.

b. Predictors: (Constant), Clear Company Policies \& Objectives, Effective CG mechanism.

c. Predictors: (Constant), Clear Company Policies \& Objectives, Effective CG mechanism, Clear Role and Authority.

d. Dependent Variable: Ownership and Control.

\section{Conclusions}

This paper investigates the corporate governance effect on ownership and control. In view of results and extensive literature review, we found that company should have clear company policies and objectives that can reduce principal agent problems. Effective corporate governance really matters to handle shareholders issues. This paper to explore corporate governance effect on ownership and control of firms. We found that ownership and control problem can be reduced, if a firm has clear policies and objectives which will create a clear line between the manager and the shareholders of company. However, from results we can state that principal-agent problem and ownership and control can be eliminate through clear company policies and objectives. 


\section{References}

Becher, D. A., \& Campbell, T. L. (2004). Corporate governance of bank mergers. Proceedings-Federal Reserve Bank of Chicago, 267-287.

Berle, A. A., \& Means, G. C. (1932). The Modern Corporation and Private Property. New York: Macmillan.

Core, J. E., Holthausen, R. W., \& Larcker, D. F. (1999). Corporate governance, chief executive officer compensation, and firm performance. Journal of Financial Economics, 51(3), 371-406. $\mathrm{http}: / / \mathrm{dx}$.doi.org/10.1016/S0304-405X(98)00058-0

Farinha, J. (2003). Corporate Governance: A Survey of the Literature.

Himmelberg, C. P., Hubbard, R. G., \& Palia, D. (1999). Understanding the determinants of Ownership and the link between Ownership and Performance. Journal of Financial Economics, 53, 353-384. http://dx.doi.org/10.1016/S0304-405X(99)00025-2

Jensen, M. C., \& Meckling, W. H. (1976). Theory of the Firm: Managerial Behaviour, Agency Costs and Ownership Structure. Journal of Financial Economics, 3(4), 305-360. http://dx.doi.org/10.1016/0304-405X(76)90026-X

Kowalewski, O., Stetsyuk, I., \& Talavera, O. (2007). Corporate governance and dividend policy in Poland.

La Porta, R., Lopez-De-Silanes, F., \& Shleifer, A. (2000). Investor protection and corporate governance. Journal of Financial Economics, 58(1-2), 3-27. http://dx.doi.org/10.1016/S0304-405X(00)00065-9

McColgan, P. (2001). Agency theory and corporate governance: a review of the literature from a UK perspective. Department of Accounting \& Finance, University of Strathclyde, Glasgow.

Novikova. (2004). The Impact of Internal Corporate Governance System on Firms Innovative Activities. Research design to be presented at the DRUID Academy's Winter Conference on Innovation. Growth and Industrial Dynamics Aalborg, Denmark

Okeahalam, C., \& Akinboade, O. A. (2003). A Review of Corporate Governance in Africa: Literature, Issues and Challenges. Global Corporate Governance Forum.

Oman, C. P. (2001). Corporate Governance and National Development. An outgrowth of the OECD Development Centre s Experts Workshop in 2000 and Informal Policy Dialogue in 2001 sponsored in part by CIPE.

Shleifer, A., \& Vishny, R. W. (1997). A survey of corporate governance. The journal of finance, 52(2), 737-783. http://dx.doi.org/10.1111/j.1540-6261.1997.tb04820.x

\section{Notes}

Note 1. Manual of corporate governance, SECP.

Note 2. Manual of corporate governance, Securities and Exchange Commission of Pakistan (p. 1).

Note 3. Manual of corporate governance, Securities and Exchange Commission of Pakistan (p. 7).

Note 4. Manual of corporate governance, Securities and Exchange Commission of Pakistan (p. 5).

Note 5. Kenneth Scott of Stanford Law School, (March 1999) taken from Manual of corporate governance, Securities and exchange commission of Pakistan (pp. 5-6).

\section{Copyrights}

Copyright for this article is retained by the author(s), with first publication rights granted to the journal.

This is an open-access article distributed under the terms and conditions of the Creative Commons Attribution license (http://creativecommons.org/licenses/by/3.0/). 